Kovács Petra ${ }^{1}$

\title{
A brit radarrendszer müködése az angliai csata idején
}

\section{The Operation of the British Radar System during the Battle of Britain}

\begin{abstract}
Absztrakt
Az angliai csatát a 20. század legnagyobb légi csatájaként tartják számon, amikor is a német Luftwaffe és a Brit Királyi Légierö (Royal Air Force, RAF) vívott több hónapos küzdelmet a Nagy-Britannia feletti légi uralom megszerzéséért. A két világháború között nagyarányú fejlesztések indultak meg a haditechnika terén. Mind a németek, mind a britek azon voltak, hogyan tudják megszerezni a másik fél terveit, és miként lesznek képesek megvédeni a sajátjaikat.
\end{abstract}

Kulcsszavak: angliai csata, információs müveletek, radarrendszer, Enigma

\begin{abstract}
The Battle of Britain is considered to be the greatest air battle of the twentieth century, when the German Luftwaffe and the British Royal Air Force fought for months to gain air control over Britain. Between the two World Wars, large-scale developments in military technology began. Both the Germans and the British were keen on how to get the other party's plans and how to defend their own.
\end{abstract}

Keywords: Battle of Britain, information operations, radar system, Enigma 


\section{Bevezetés}

A 20. században a belső égésű motor, a drót nélküli távírógép feltalálásának következtében - és még sok más eseménynek köszönhetően -, jelentősen megváltozott a háború jellege. ${ }^{2} \mathrm{Az}$ angliai csatát a II. világháború egyik döntő csatájának nevezhetjük. 1940. július 10. és 1940. október 30. között a Brit Királyi Légierő és a Luftwaffe által megvívott ütközetek során Nagy-Britannia biztosította saját függetlenségét a kor új haditechnikai vívmányainak segítségével. ${ }^{3}$ A németek célja az volt, hogy a Luftwaffe segítségével Nagy-Britanniát térdre kényszerítsék, amilyen gyorsan csak lehet. ${ }^{4}$ A háború kirobbanása előtt mind a britek, mind a németek igyekeztek olyan technikai vívmányokat fejleszteni, amelyekkel hatékonyan be tudták mérni az ellenfél pontos helyzetét, továbbá képesek voltak információt gyűjteni annak lehetséges további lépéséről, azaz céljuk az információs fölény kialakítása volt.

A briteknek két nagy előnye volt: egyrészt, kiépítettek egy jól működő radarrendszert, valamint hogy sikerült megfejteniük a németek által feltörhetetlennek hitt Enigma rejtjelét. Mindezekre támaszkodva a Vadászrepülő Parancsnokság vezetése hatékonyan tudta a csapatokat a megfelelő időben a megfelelő helyre vezényelni.

\section{Az Enigma}

Az Enigma kódjainak feltörése a brit katonai hírszerzés egyik fö feladata volt. Ahhoz, hogy megértsük a kódfejtés fontosságát, kissé vissza kell mennünk az időben.

Az embereket mindig is érdekelte, hogyan tudnak úgy üzeneteket továbbítani a saját célra, hogy az illetéktelen kézbe jutva ne legyen megfejthető. Julius Caesar alkalmazta először a rejtjelezést katonai célra. Ő még az úgynevezett monoalfabetikus kódolást használta, amely azt jelentette, hogy a betűket az ábécében meghatározott számmal arrébb levővel helyettesítette. ${ }^{5}$

Az Enigmát Arthur Scherbius német mérnök találta fel 1918-ban, de csak 1923-ban került piacra. Több változtatáson ment keresztül, míg végül a $C$ modellt fogadta el a német hadsereg, és azt kezdte el alkalmazni, amely egyébként kereskedelmi forgalomban kapható volt.

Maga a gép ránézésre leginkább egy írógéphez hasonlít. Müködésének lényege, hogy a leütött billentyüket elektromos áram felhasználásával kódolta át a szerkezet egy másik betűvé. Tette ezt oly módon, hogy a beépített tárcsák különböző idöközönként elfordultak, változtatva ezzel a leütött billentyú kódjelét, a 3 tárcsás verzióban 9-szer kódolódtak át a betűk, míg felvillant a végső megfelelője. Megfejtésének nehézségét az adta, hogy a tárcsák felcserélhetők, számuk növelhető volt, naponta változtatták a beállításokat, valamint kellett hozzá egy kódkönyv, amelyben meg voltak adva a következő információk napra pontosan lebontva:

Len Deighton: Vadászrepülök. Az angliai légi csata története. Budapest, Európa, 2013. 139.

John Keegan: A második világháború. Budapest, Jaffa, 2019.

Antony Beevor: The Second World War. London, Weidenfeld \& Nicolson, 2012. 149.

Liptai Kálmán: Kriptográfia. Eger, Eszterházy Károly Főiskola, 2011. 
- a tárcsák száma és behelyezési sorrendje,

- a kapcsolótáblán lévő 10 betűpár összekötése,

- a tárcsák elfordításával a tárcsák kezdőpozíciói. ${ }^{6}$
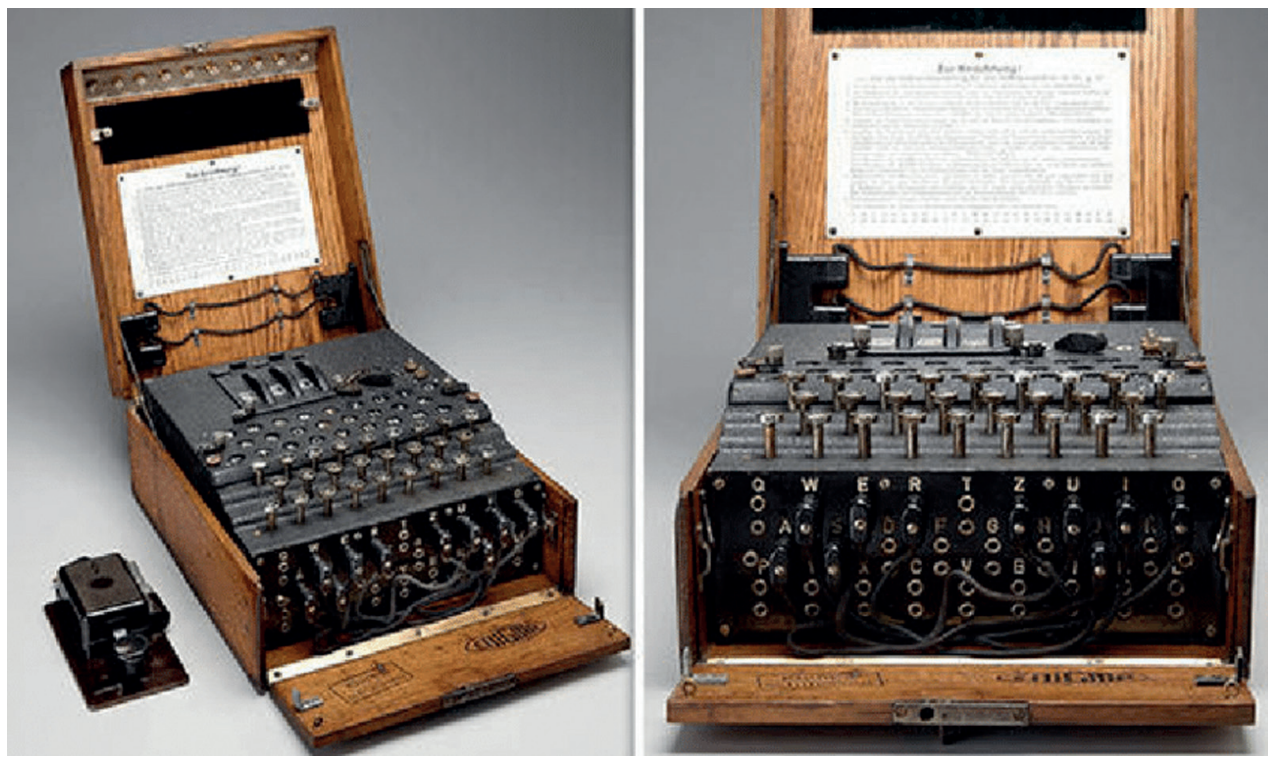

1. ábra: Az Enigma

Forrás: www.researchgate.net/figure/Enigma-machine-3_fig1_333293844 (A letöltés dátuma: 2020. 05. 14.)

1930-ban Lengyelországban három poznani matematikus - név szerint: Marian Rejewski, Henryk Zygalski, Jerzy Rózycki - megkezdte az Enigma rejtjelezésének feltörését. Megszerezték az Enigma napi beállításait két hónapra visszamenően egy brit kémnek köszönhetően, valamint mivel maga a készülék is kapható volt, 1933-ra sikerült rekonstruálniuk a 3 forgótárcsát. 1938-ra megépítettek egy szerkezetet, amely a Bomba nevet kapta, és két óra alatt képes volt megfejteni az Enigma aznapi beállításait. Innentől kezdve az sem volt akadály, hogy minden éjfélkor változtak az Enigma beállításai. 1939-ben a németek 5-re növelték a tárcsák számát. A lengyelek érzékelték, hogy a németek készülhetnek valamire, ezért átadták a szövetséges franciáknak és briteknek az addigi eredményeiket, ${ }^{7}$ akik ennek hatására létrehozták az úgynevezett „Bletchley Park"-ot. Itt mintegy 11 ezer ember dolgozott azon az „Ultra” fedőnevü projekt egy részén, amelynek célja az volt, hogy megfejtsék a németek operatív üzeneteit. Alan Turing a lengyel kutatások továbbfejlesztéseként megépítette a Colossust, amelybe 36 Enigmát szerelt. A briteknek ekkortól sikerült minden üzenetet megfejteniük, ám ezt a legnagyobb titokban kellett tartaniuk. Tették ezt oly módon, hogy például

\section{Az Enigma. Lazarbibi.}

Stuart Milner-Barry: Hut 6: Early days. In F. H. Hinsley Alan Stripp (eds.): Codebreakers: The Inside Story of Bletchley Park. Oxford University Press, 2003. 89-99. 
szándékosan nem vették figyelembe az egyes támadásokról szóló üzeneteket. És erről a világnak körülbelül az 1970-es évekig fogalma sem volt. ${ }^{8}$

Ahogy korábban említettem, a szemben álló felek célja az információs fölény kialakítása volt. A technikai képességek az információ titkosított továbbítására, illetve annak megszerzése folyamatára fókuszálnak. Az Enigma esetében német oldalról a technikai képesség az maga a szerkezet, brit oldalról pedig a kód feltöréséhez szükséges gépezet (Colossus) megépítése.

A kognitív (megismerő) képességek célpontja az ember. Ezen képesség szempontjából a megtévesztés kognitív képességeiről beszélhetünk, vagyis: a kódok megfejtése nagyban befolyásolta a stratégiai tervezés irányát; valamint hamis információkat, illetve fedősztorikat szivárogtattak ki annak érdekében, hogy a németek ne jöjjenek rá, miszerint feltörték a rejtjelüket. ${ }^{9}$

\section{A radarrendszer}

„Az információs műveletek az információs környezetben érvényesülő információs képességek integrált, összehangolt és koordinált alkalmazására irányuló tevékenységek összessége, amelyek a müveletek célkitűzéseinek elérése érdekében, kognitív képességekkel közvetlenül, illetve technikai képességekkel közvetett hatásokat gyakorolnak a müveletekben részt vevő célközönség szándékára, helyzetértelmezésére és képességeire."10

A technikai képességek az információ megszerzésére fókuszálnak. A radarrendszerek kiépítése meglehetősen nagy elörelépésnek számított.

1935-ben az angol Robert Watson-Watt beadványt nyújtott be a Légügyi Minisztériumnak, amely a repülőgépek rádióval történő helymeghatározásának elvét tartalmazta, továbbá ennek katonai felhasználhatósága jelentőségét. Még ugyanebben az évben elkezdték az első öt-öt 21 méter magas radarállomás telepítését a Temze mindkét oldalán. A lokátorok a háború alatt már akkor érzékelték a német gépeket, amikor azok Franciaországban felszálltak. A háború kezdeti szakaszára a radarok száma 20-ra nőtt. Hátrányuk azonban az volt, hogy csak a 4500 méteres magasságon felülröl érkező gépeket tudták bemérni. Annak érdekében, hogy a 4500 méter alatt berepülö ellenséges gépek is érzékelhetőek legyenek, a britek kiépítették a honi radarláncot (Chain Home Low, CHL). Ezeket a forgó antennájú radarokat először a haditengerészet alkalmazta, onnan emelték át a légi felderítés érdekében.

A radarok által jelzett repülőgép helyzetét az alábbi módszerekkel állapították meg: a repülőről visszaverődő rádiójel beérkezésének idejéből megállapították a gép távolságát, a két szomszédos toronyállomáshoz beérkező rádiójel metszéspontja pedig kiadta az irányát."1 Üzembe helyezésük során felmerült annak a problémája, hogy miként különböztethetőek meg a saját csapatok gépei az ellenség gépeitől. 1938-ra a britek

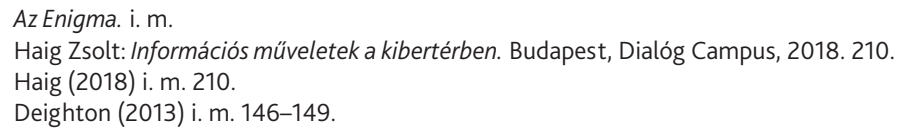


gépeit felszerelték egy úgynevezett „felelökészülékkel”, amely erősebb jelet sugárzott vissza a radar frekvenciáján, ezáltal beazonosíthatók lettek a baráti repülőgépek.

A radarok által megjelenített információkat a honi radarállomásokról telefonon továbbították a Bentley-apátságba, majd miután itt meggyőződtek azok pontosságáról és hitelességéről, továbbították őket a hadműveleti termekbe. A termek közepén állt a térképasztal, amelyeken az egyes csapatokat, repülőket jelző korongokat tologatták az ott dolgozó hölgyek. A korongok az alábbi információkkal voltak ellátva: a gépek száma és becsült magassága, repülési iránya, valamint az alakulat hivatkozási száma. ${ }^{12}$

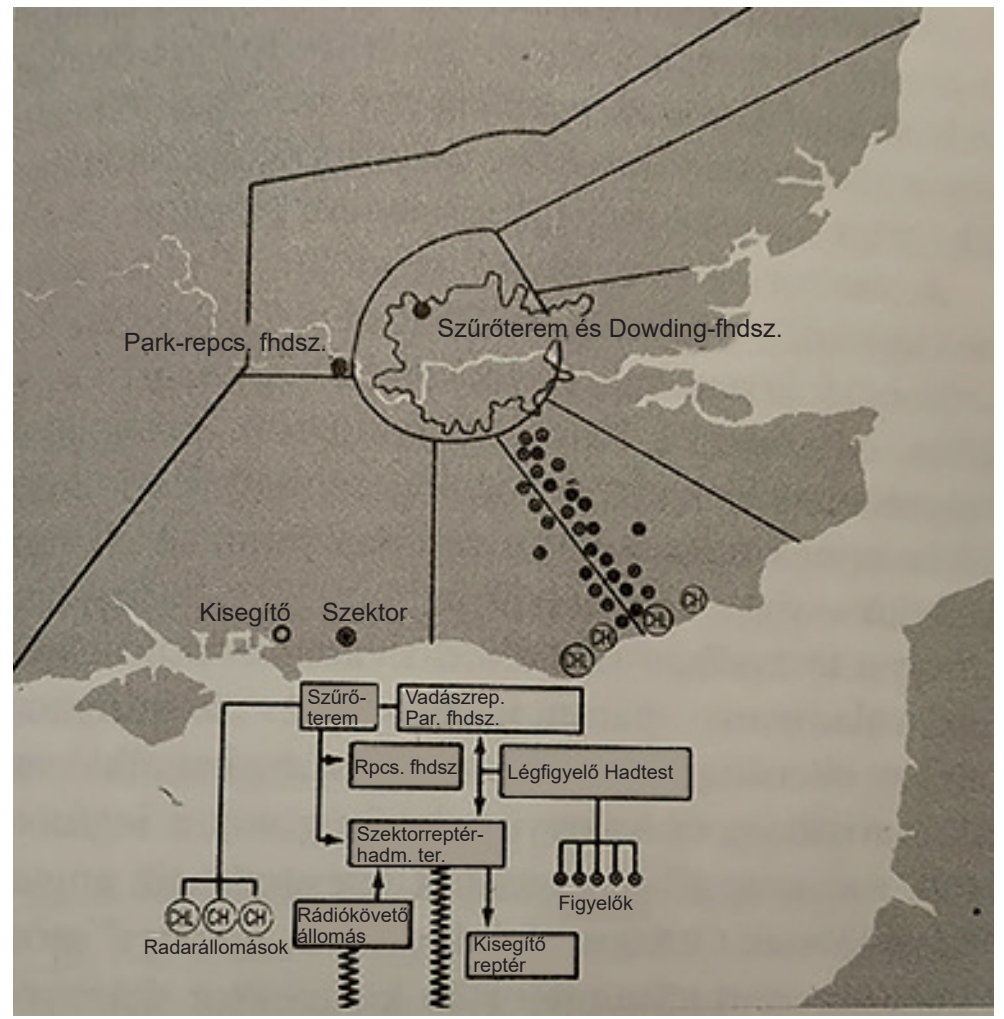

2. ábra: A rendszer

Forrás: Deighton (2013) i. m. 159.

A RAF vadászpilótái közötti rádiókommunikációk a központi repülőtereken berendezett szektor-vadásziránytó terembe érkeztek be. A rádiózás könnyű lehallgatása végett jelszavakat alkalmaztak. "Ilyen szavak voltak például: angels (angyalok): ez az ezer láb magasság, pancake (palacsinta): leszállás; illetve bandits (banditák): az ellenséges gépek a láthatáron."13

Deighton (2013) i. m. 154.

13 Robert Gretzyngier - Wojtek Matusiak: Polacy w obronie Wielkiej Brytanii. Wydanie I., Poznań, Dom Wydawniczy REBIS, 2007. 22. 


\section{A Vadászrepülö Parancsnokság}

1936. július 14-én a Brit Királyi Légierő kibővítésének eredményeként a Légügyi Tanács úgy határoz, hogy Nagy-Britannia légvédelmének megerősítéséért négy parancsnokságot hoz létre:

- Bombázó Parancsnokság - Sir John Steel légi marsall parancsnokságával, bázisa: Uxbridge;

- Vadászrepülö Parancsnokság - Sir Hugh Dowding légi marsall parancsnoksága alatt -, aki Sir Frederick Pile szerint: „Nehéz természetű; konokul önfejü; hallatlanul elszánt ember, aki mindenkinél többet tud a légi hadviselés minden kérdéséröl." ${ }^{14}$ - Stanmore központtal;

- Tengerparti Parancsnokság - parancsnoka Sir Arthur Longmore légi marsall, Lee-on-Solent központtal;

- Kiképző Parancsnokság - Sir Charles Burnett légi marsall vezetésével, Ternhill központtal.

A parancsnokok a parancsnokságuk megtervezéséért és fejlesztéséért voltak felelősek, míg a légierő vezérkari fönöke - Sir Cyril Newall marsall - továbbra is a politikai célok megfelelő végrehajtását kapta fö feladatul. ${ }^{15}$

A Vadászrepülő Parancsnoksághoz szintén megküldték a hadműveleti termekből a szektorrepülőterekre továbbított radarinformációkat. A Parancsnokság termeiben dőlt el a légiriadók elrendelése, valamint határoztak a BBC-adások beszüntetéséröl a német pilóták rádiótorony általi iránymérésének megakadályozásának érdekében. ${ }^{16}$

A légvédelem a fentieken kívül négy vadászrepülő-csoportra támaszkodott. A Vadászrepülő Parancsoksághoz tartozott hét légvédelmi tüzérhadosztály, fényszóróegységek, a figyelő- és jelzőhadtest ${ }^{17}$ és a Záróléggömb Parancsnokság (Balloon Command). Ám ez utóbbiakra most nem térek ki bővebben. ${ }^{18}$

\section{5. Összegzés}

A technika fejlődése, a megfejtett kódolt üzenetek, valamint a radarjelentések megfelelő alakulatokhoz kerülése óriási előnyt jelentett az anyaországnak: csapataik pontosan felkészülhettek a várható támadásra, esetenként meg is előzhették azokat.

A fentieket összegezve: a britek légi fölényének kivívásában, ezáltal a csata megnyerésében is óriási szerepe volt, amely nagyban hozzájárult a II. világháború végkimeneteléhez.

Véleményem szerint azonban, ahogy Sir William Stephenson állította: „A második világháború történetét a titkos hadviselés tényeinek ismeretében vizsgálva meglepő

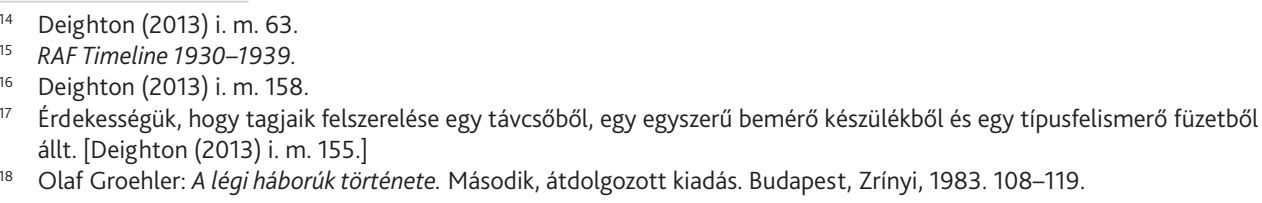

18 Olaf Groehler: A légi háborúk története. Második, átdolgozott kiadás. Budapest, Zrínyi, 1983. 108-119. 
következtetés adódik: A küzdelmet végső soron nem a pusztító hadi gépezetek döntötték el, hanem az, hogy a szabad ember legyőzhetetlen, hogy a szabad lélek leleményes. Az emberi ellenállás szellemét nem törheti meg a puszta technológia", ${ }^{19}$ az angliai csatát sem sikerült volna megnyernie a briteknek a Vadászrepülő Parancsnokság pilótái valamint az összes háttérben dolgozó személy elhivatottsága nélkül. Valóban fontosnak tartom a technológiai fejlesztéseket, és bár elismerem, hogy az emberi elme nélkülözhetetlen, de önmagában nem elég egy háború megnyeréséhez, mint ahogy önmagában a technikai fölény kialakítása sem. Azonban ha ez a kettő egyensúlyban van, és a megfelelő vezetés kezébe kerül, komoly sikerek érhetőek el. Ezt bizonyítja Sir Hugh Dowding marsall eredményessége.

\section{Felhasznált irodalom}

Az Enigma. Lazarbibi. Elérhető: https://lazarbibi.blog.hu/2015/10/18/az_enigma (A letöltés dátuma: 2020. 05. 08.)

Beevor, Antony: The Second World War. London, Weidenfeld \& Nicolson, 2012.

Deighton, Len: Vadászrepülök. Az angliai légi csata története. Budapest, Európa, 2013. Enigma (gép). Wikipédia. Elérhető: https://hu.wikipedia.org/wiki/Enigma_(g\%C3\%A9p)\#cite_note-3 (A letöltés dátuma: 2020. 05. 08.)

Gretzyngier, Robert - Wojtek Matusiak: Polacy w obronie Wielkiej Brytanii. Wydanie I., Poznań, Dom Wydawniczy REBIS, 2007.

Groehler, Olaf: A légi háborúk története. Második, átdolgozott kiadás. Budapest, Zrínyi, 1983.

Haig Zsolt: Információs müveletek a kibertérben. Budapest, Dialóg Campus, 2018. Keegan, John: A második világháború. Budapest, Jaffa, 2019.

Liptai Kálmán: Kriptográfia. Eger, Eszterházy Károly Főiskola, 2011. Elérhető: https:// regi.tankonyvtar.hu/hu/tartalom/tamop425/0038_matematika_Liptai_KalmanKriptografia/ch02.html (A letöltés dátuma: 2020. 05. 07.)

Milner-Barry, Stuart: Hut 6: Early days. In F. H. Hinsley Alan Stripp (eds.): Codebreakers: The Inside Story of Bletchley Park. Oxford University Press, 2003. 89-99.

RAF Timeline 1930-1939. Elérhetö: https://web.archive.org/web/20090825140423/ http://www.raf.mod.uk/history/raftimeline_19301939.cfm (A letöltés dátuma: 2020. 05. 22.)

19 Enigma (gép). Wikipédia 